\title{
Refining the Derogation Test on Material Tax Selectivity: The Equality Test
}

\author{
Begoña Pérez-Bernabeu*
}

The research focuses on the problems that the ECJ has found in recent cases at applying the classic three step selectivity test in the area of taxation. The Court is confronted with the Member States' attempt to circumvent the State aid rules by creating ad hoc general tax systems so there is no general system against which the tax measures can be assessed. In order to avoid this circumvention, the ECJ has shifted its case law on material tax selectivity towards a new "comparability test" (also called "equality test") based on a non-formalistic approach which takes into account the underlying objectives of the tax measure. This "comparability test" encompasses an objectives-based approach which provides Member States a higher degree of freedom. However it seems to be rather vague because it involves the difficult task of distinguishing permissible goals from impermissible goals which irretrievably leads us to a case-by-case analysis which does not provide the desirable degree of legal certainty and predictability. The main conclusion of this research is that the criterion of material tax selectivity is not definitively formulated in the ECJ case law but, on the contrary, it is open to refinements in order to meet the challenges that current and future State aid cases may raise.

Keywords: Material Selectivity; Tax; Derogation; Equality Test.

\section{Preliminary Remarks}

\section{Tax Measures as State Aid}

Since the entry into force of the Treaty of Rome, the European Court of Justice (hereafter ECJ) applied State aid disciplines to tax measures as early jurisprudence shows in cases 30/59, De Gesamenlijke Steenkolenmijnen in Lumburg vs. High Authority of the European Coal and Steel Community ${ }^{1}$ and 173/73, Italian Republic vs. Commission of the European Communities. ${ }^{2}$ Taxation was not the initial focus of the State aid rules, but the European judicature made it clear in some early judg- ments that the restriction applies to all forms of public aid including all kinds of relief from taxation normally imposed and that the restriction does not distinguish between measures of State intervention in respect to their causes or their aims but solely to their effects. ${ }^{3}$

However the Commission's practice set aside tax measures while examining State Aid measures over decades, arguing that they involved an intervention in a sovereign policy area of the Member States. It was not until the 9os that the Commission decided to apply State aid law systematically to tax measures within a new legal framework aimed at tackling harmful tax competition. ${ }^{4}$

\footnotetext{
Begoña Pérez-Bernabeu, Associate Professor, Tax Law Department, Faculty of Law, University of Alicante, Spain. This paper falls within the framework of a research project funded by the Spanish Ministry of Economy and Competitiveness, Reference DER2015-68072-P (MINECO/FEDER) of which the author is Principal Investigator of the research team. Moreover, the author is also a member of the Research Group of Excellence PROMETEO/2016/053, funded by the Spanish Regional Government of the Comunidad Valenciana (Conselleria de Educación, Investigación, Cultura y Deporte, Generalitat Valenciana).
}

1 Case 30/59 De Gezamenlijke Steenkolenmijnen in Limburg v High Authority of the European Coal and Steel Community [1961] ECR I-0001.

2 Case C-173/73 Italy v Commission [1974] ECR I-709.

3 P Rossi-Maccanico, 'The Gibraltar Judgment and the point on selectivity in fiscal aids' (2009) 2 EC Tax Review, 67, 67.

4 C Micheau, 'Tax selectivity in European Law of State Aid: legal assessment and alternative approaches' (2015) 3 European Law Review, 323, 323. 
Nowadays the Commission's rules with regard to State aid assessment are provided in the Commission Notice on the notion of State aid as referred to in $\mathrm{Ar}$ ticle 107(1) of the Treaty on the Functioning of the European Union. ${ }^{5}$

\section{Selectivity in State Aids}

There is no legal definition of "general" or "selective" measures in the acquis communautaire. ${ }^{6}$ Moreover the ECJ hardly provides a definition of 'general' measures, thus the discussed notions are purely doctrine based. $^{7}$

Already in its early case law, the Court has developed a tax selectivity test in the landmark judgment Italian Textile (Case 173/73), where it ruled that a tax measure is to be considered selective if it is intended to partially exempt undertakings from charges arising from the normal application of the general system of taxation. The ECJ has since then repeatedly held that selective advantages exist where a measure departs from the normal application of the tax system.

The concept of selectivity consists of two components. One of them is the geographical selectivity, under which a State measure is selective if undertakings located in a specific part of the territory of a Member State receive a different (better) treatment than in the rest of the territory.

In order to assess regional selectivity, the Commission remarks that, following the rationale of the established case law, ${ }^{8}$ three scenarios must be distinguished. In this context, case law has so far only dealt with tax measures. However, as regional selectivity is a general concept, the principles set out by the Union Courts as regards tax measures apply to other types of measures as well. ${ }^{9}$

In the first scenario the central government of a Member State unilaterally decides to apply a lower level of taxation within a defined geographical area.

The second scenario corresponds to symmetrical devolution of tax powers - a model of distribution of tax competences in which all infra-State authorities at a particular level (regions, districts or others) of a Member State have the same autonomous power in law to decide the applicable tax rate within their territory of competence, independently of the central government. In this case, the measures decided by the infra-State authorities are not selective as it is im- possible to determine a normal tax rate capable of constituting the reference framework.

In the third scenario - the asymmetrical devolution of tax powers - only certain regional or local authorities can adopt tax measures applicable within their territory. In this case, the assessment of the selective nature of the measure at stake depends on whether the authority concerned is sufficiently autonomous from the central government of the Member State. This is the case when the following cumulative criteria of autonomy are fulfilled: institutional, procedural, and economic and financial autonomy. If all of these criteria of autonomy are present when a regional or local authority decides to adopt a tax measure applicable only within its territory, then the region in question, not the Member State, constitutes the geographical reference framework.

The Commission summarises the content of these three criteria of autonomy. Firstly, the existence of institutional autonomy can be established where the tax measure decision has been taken by a regional or local authority with its own constitutional, political and administrative status that is separate from that of the central government. The assessment of whether this criterion has been fulfilled in each individual case should include, in particular, examination of the constitution and other relevant laws of a given Member State so as to verify whether a given region indeed has its own separate political and administrative status and whether it has its own selfgoverning institutions which have the power to exercise their own fiscal competence. ${ }^{10}$

In respect to the existence of procedural autonomy, the Commission considers that it can be estab-

5 European Commission, Notice of 19 July 2016 on the notion of State aid as referred to in Article 107(1) of the Treaty on the Functioning of the European Union, 2016/C 262/01, OJ C 262, 19.7.2016, p. 1-50

6 P Nicolaides, M Kekelekis and P Buyskes, State Aid Policy in the European Community: A Guide for Practicioners (Kluwer Law International 2005), 25.

7 J Kociubiński, 'Selectivity criterion in state aid control' (2012) 2(1) Wroclaw Review of Law, Administration \& Economics, 1, 4.

8 Case C-88/03 Portugal $v$ Commission [2006] ECR I-07115, [57] et seq. and Joined Cases C-428/06 to C-434/06 Unión General de Trabajadores de La Rioja, [2008] I-06747, [47] et seq.

9 European Commission, Notice of 19 July 2016 on the notion of State aid as referred to in Article 107(1) of the Treaty on the Functioning of the European Union, 2016/C 262/01, paragraph 143.

10 European Commission, Notice of 19 July 2016 on the notion of State aid as referred to in Article 107(1) of the Treaty on the Functioning of the European Union, 2016/C 262/01, paragraphs 145-146. 
lished when a tax measure decision has been adopted without the central government being able to directly intervene in determining its content. The essential criterion for determining whether procedural autonomy exists is not the extent of the competence that the infra-State body is recognised as having, but the capability of that body, in view of its competence, to adopt a decision on a tax measure independently, that is to say without the central government being able to intervene directly as regards its content.

The fact that a consultation or conciliation procedure exists between the central and regional (or local) authorities to avoid conflicts does not automatically mean that an infra-State body does not have procedural autonomy, provided that that body, and not the central government, has the final word on the adoption of the measure at stake. The mere fact that the acts which an infra-State body adopts are subject to judicial review does not in itself mean that that body lacks procedural autonomy, since the existence of such review is an inherent feature of the rule of law. A regional (or local) tax measure does not have to be completely separate from a more general tax system for not being considered State aid. In particular, it is not necessary that the tax system in question (bases of assessment, tax rates, tax recovery rules and exemptions) is fully devolved to the infra-State body. For example, corporate tax reimbursement limited to the power to vary rates within a limited range, without devolving the power to change the bases of assessment (tax allowances and exemptions, etc.), could be considered as fulfilling the procedural autonomy condition if the pre-defined rate bracket allows the region concerned to exercise meaningful autonomous powers of taxation, without the central government being able to directly intervene as regards the policy content. ${ }^{11}$

Finally, according to the Commission the existence of economic and financial autonomy can be estab-

11 European Commission, Notice of 19 July 2016 on the notion of State aid as referred to in Article 107(1) of the Treaty on the Functioning of the European Union, 2016/C 262/01, paragraphs 147-151.

12 European Commission, Notice of 19 July 2016 on the notion of State aid as referred to in Article 107(1) of the Treaty on the Functioning of the European Union, 2016/C 262/01, paragraphs 152-155.

13 European Commission, Notice of 19 July 2016 on the notion of State aid as referred to in Article 107(1) of the Treaty on the Functioning of the European Union, 2016/C 262/01, paragraphs 152-155. lished where an infra-State body assumes responsibility for the political and financial consequences of a tax reduction measure. This cannot be the case if the infra-State body is not responsible for managing a budget, that is to say when it does not have control of both revenue and expenditure. Therefore, in establishing the existence of economic and financial autonomy, the financial consequences of the tax measure in the region must not be offset by aid or subsidies from other regions or the central government. Hence, the existence of a direct causal link between the tax measure adopted by the infra-State body and the financial support from other regions or the central government of the Member State concerned rules out the existence of such autonomy. ${ }^{12}$

The existence of economic and financial autonomy is not undermined by the fact that a shortfall in tax revenues as a result of the implementation of devolved tax powers (for example a lower tax rate) is offset by a parallel increase in the same revenues due to the arrival of new businesses attracted by the lower rates. The autonomy criteria do not require the rules governing tax collection to be devolved to the regional or local authorities, nor do they require the tax revenues to actually be collected by those authorities. The central government may continue to be responsible for collecting devolved taxes if the collection costs are borne by the infra-State authority. ${ }^{13}$

On the other hand, material selectivity encompasses all forms of unequal treatment of public authorities. Material selectivity may be established by law or de iure selectivity (when the legislation explicitly awards tax advantages to certain undertakings) or in fact or de facto selectivity (when the advantage is not expressly awarded by law and only a case-by-case analysis can reveal the selectivity of the measure).

When Member States adopt ad hoc positive measures benefitting one or more identified undertakings (for instance, granting money or assets to certain undertakings), it is normally easy to conclude that such measures have a selective character, as they reserve favourable treatment for one or a few undertakings. The situation is usually less clear when Member States adopt broader measures applicable to all undertakings fulfilling certain criteria, which mitigate the charges that those undertakings would normally have to bear (for instance, tax or social security exemptions for undertakings fulfilling certain criteria). In such cases, the selectivity of the measures should normally be assessed by means of an analy- 
sis that involves an effects-based approach in the field of general measures or that consists of a three-steps analysis, in the field of tax measures, as explained below.

\section{Assessing Material Selectivity in State Aids: The Effects-Based Approach}

\section{The Commission Practice: from the Effects-On-Rivals Approach to the Effects-Based Approach}

Past practice seems to have focused on the impact of State aid on competitors' profits. In this context, the European Commission and the ECJ interpreted the concept of State aid broadly, so the legal requirement that aid must have a potential effect on competition and trade between Member States was easily satisfied. $^{14}$

In the past the Commission considered that "State aid must be selective and thus affect the balance between certain firms and their competitors" and to prove this "it is sufficient if it can be shown that the beneficiary is involved in an economic activity and that he operates in a market in which there is trade between Member States". ${ }^{15}$ This brief description of the criteria defining State aid shows that the scope of Community State aid rules is wide (but not openended).

Heidhues and Nitsche remark that formerly, the analysis of whether aid does adversely affect trading conditions to an extent contrary to the common interest has rarely involved a coherent economic analysis of the effects of State aid on competition. Indeed, these authors clarify that there have been only very few cases where the effect on competition and trade was analysed by the Commission in detail and played a role in the decision adopted. This implies that yesteryear the European Commission was likely to have allowed aid that harms competition while at the same time forbidding aid that would have been beneficial. ${ }^{16}$ Consequently, these authors conclude that there are obvious arguments as to why simply equating "distortion of competition" with "less rivalry" is not appropriate and that competition should be a means to an end and not an end in itself. ${ }^{17}$

Due to these problems and since the ECJ considered that the Commission had not adequately looked at the economic evidence in Airtours and Tetra Laval-
ISidal, the European Commission strengthened, through its administrative practice, a trend towards a more effects-based analysis in EU competition policy that applied both to the assessment of competition cases, where more emphasis was put on the analysis of facts, as well as to the development of soft law.

But it was in 2005 when a paradigm shift took place in State aid control with the move towards a "more economic approach" in the State Aid Action Plan (SAAP), ${ }^{18}$ a far-reaching reform package in terms of EU State aid control whose aim is to promote better-targeted aid while offering better predictability of State aid, better economic results and better governance. ${ }^{19}$ The SAAP claims for "a refined economic approach" when assessing State aid by means of "making more use of a refined economic approach is a means to ensure a proper and more transparent evaluation of the distortions to competition and trade associated with state aid measures". ${ }^{20}$

On the basis of economic analysis ${ }^{21}$ a series of measures are offered to Member States to grant aid and to better target their funds to measures that are on balance beneficial to the common interest.

The main novelty that the new refined economic approach brought was the adoption of the balancing test which is applied only in the second stage of the assessment of State aid in order to study the compatibility of the measure with the provisions of Article

14 P Heidhues and R Nitsche, 'Comments on State aid reform. Some implications of an effects-based approach' (2006) 1 European State Aid Law Quarterly, 23, 24

15 European Commission, Staff Working Document of 15 of November 2004 Vademecum Community Rules on State Aid, SEC(2004) $1453,3-4$

16 P Heidhues and R Nitsche, 'Comments on State aid reform. Some implications of an effects-based approach' (2006) 1 European State Aid Law Quarterly, 23, 24.

17 P Heidhues and R Nitsche, 'Study on methods to analyse the impact of State aid on competition' (2006) 244 Economic Papers (European Economy, European Commission, Directorate-General for Economic and Financial Affairs), 5.

18 European Commission, State Aid Action Plan (SAAP). Less and better targeted State aid: a roadmap for State aid reform 2005-2009, COM(2005) 107 final.

19 L Roeller and O Stehmann, 'The year 2005 at DG Competition: the trend towards a more effects-based approach' (2008) 28 Review of Industrial Organization, 281, 286 and 304.

20 European Commission, State Aid Action Plan (SAAP). Less and better targeted State aid: a roadmap for State aid reform 2005-2009, COM(2005) 107 final, paragraph 22.

21 The 2006 R\&D\&I Framework was the first application of the refined economic approach advocated by the 2005 State Aid Plan, $\operatorname{COM}(2005) 107$ final. 
107(3) TFEU. The objective of the balancing test is to show that some measures adopted by Member States raise economic efficiency without causing excessive distortion of intra-Community trade and competition.

The balancing test consists of three questions assessing the positive and negative effects of the planned measure. In particular, the balancing test specifies that State aid is only acceptable insofar as:

a) It addresses a well-defined market failure.

b) It is well targeted.

c) It does not distort competition too much so that it can be on balance compatible with the common market.

In light of these positive and negative elements, the Commission balances the effects of the measure and determines whether the resulting distortions adversely affect trading conditions to an extent contrary to the common interest. The analysis in each particular case will be based on an overall assessment of the foreseeable positive and negative impacts on the given State aid. In doing this, the Commission does not work mechanically, but makes an overall assessment based on the proportionality principle.

The effects-based approach requires an evaluation of the measure adopted by a given State from an economic perspective. Roeller and Stehmann make clear that "an effects-based approach requires a careful examination of how competition works in each particular market. By focusing on the effects of company actions rather than on the form that these actions may take, an effects-based approach makes the circumvention of competition policy constraints more difficult

22 L Roeller and O Stehmann, 'The year 2005 at DG Competition: the trend towards a more effects-based approach' (2008) 28 Review of Industrial Organization, 281. 282.

23 Joined cases C-106/09P and C-107/09P Gibraltar [2011] ECR I-11113, [87].

24 P Paepe, "Taxing Games Of Chance: EU State Aid Law And The Member States' Power To Tax Games Of Chance", available at $<$ http://www.mondaq.com/x/257914/Income+Tax/ Taxing+Games+Of+Chance+EU+State+Aid+Law+And+The+Mem ber> accessed 10 January 2017.

25 Case C-487/06 P, British Aggregates [2008] ERC I-10515, [92].

26 Case C-124/10 P European Commission v Électricité de France (EDF) [2012] published in the electronic Reports of Cases (Court Reports - general), [88].

27 Joined cases C-106/09P and C-107/09P Gibraltar [2011] ECR I-11113, [87]. See also Case T-210/02 British Aggregates v Commission [2006] ERC II-02789 which was set aside by Case C-487/06 P British Aggregates [2008] ERC I-10515, [89]. for companies. At the same time, this approach provides a more consistent treatment of practices. It takes into account that many business practices may have different effects in different circumstances, distorting competition in some cases and promoting efficiencies and innovation in others. As the assessment is not based on the form of a particular practice but on the anticompetitive effect, the competition authority needs to identify a theory of harm and assess the extent to which such a negative effect on consumers is potentially outweighed by efficiency gains". ${ }^{22}$

\section{The Effects-Based Approach in Tax- Related State Aid Case Law}

The ECJ takes into consideration this effects-based approach while analysing the effects of a tax measure at issue. An example of it is the Gibraltar case, where the ECJ stated that Article 107(1) TFEU "does not distinguish between measures of State intervention by reference to their causes or their aims but defines them in relationship to their effects, and thus independently of the techniques used". ${ }^{23}$

Paepe $^{24}$ sums up the more relevant consequences of the adoption of the effects-based approach by the ECJ. In his opinion, the effects-based approach entails, firstly, that a (tax) measure cannot escape State aid control on the basis of the aims that measure is pursuing. This does not mean that the objectives pursued by a tax measure are irrelevant for State aid law purposes. The aim of the tax measure can duly be taken into account when the compatibility of a State aid measure is examined under Article 107(3) TFEU. ${ }^{25}$

Moreover, the effects-based approach also means the form of the tax measure is not decisive for its qualification as State aid or, on the contrary, to avoid such a qualification. The EU Courts ruled that the notion of State aid covers any aid granted through State resources - in any form whatsoever - which, in terms of its effects, distorts or threatens to distort competition". ${ }^{26}$ The exception from the Gibraltar case cited above underlines that State aid should be defined "independently of the techniques used". ${ }^{27}$

In spite of the effect-based approach, Paepe considers that the selectivity test, which ultimately is aimed at identifying whether the tax measure under scrutiny "favour[s] certain undertakings or the production of certain goods", needs to have regard, at least to some extent, to the form and the aim(s) of 
the tax measure whose qualification as State aid is at stake. $^{28}$

\section{Assessing Material Selectivity in Tax Measures: The Derogation Test}

As mentioned above, the Commission makes clear that when Member States adopt ad hoc positive measures benefitting one or more identified undertakings (for instance, granting money or assets to certain undertakings), it is normally easy to conclude that such measures have a selective character, as they apply favourable treatment for one or a few undertakings. The situation is usually less clear when Member States adopt broader measures applicable to all undertakings fulfilling certain criteria, which mitigate the charges that those undertakings would normally have to bear (for instance, tax or social security exemptions for undertakings fulfilling certain criteria). In such cases, the selectivity of the measures should normally be assessed by means of a three-step analysis. $^{29}$

This three-step methodological analysis - also called "derogation test" 30 - has been set up by the EU Courts and applied mainly to tax measures. This test has been applied over the years leading to refinements and due clarifications, but certain difficulties in interpretation have also emerged and there are discrepancies both in the Commission's practice and the EU Courts case law. ${ }^{31}$

The Commission's Notice on the notion of State aid as referred to in Article 107(1) of the TFEU ${ }^{32}$ refers to this three-step test and explains the scrutiny to be effectuated while applying it. ${ }^{33}$

Under the "derogation test" a measure is selective where it constitutes derogation from the standard application of the tax system. In doing this, the general tax system should first be determined and secondly the derogation from this general tax system should be appraised.

The ECJ clearly summarises this test in its judgment on the joined cases T-211/04 and T-215/04, Gibraltar vs. Commission ${ }^{34}$ stating that "in order for it to classify a tax measure as selective, it must begin by identifying and examining the common or 'normal' regime under the tax system applicable in the geographical area constituting the relevant reference framework. It is in relation to this common or "normal' tax regime that the Commission must, second- ly, assess and determine whether any advantage granted by the tax measure at issue may be selective by demonstrating that the measure derogates from that common regime inasmuch as the measure differentiates between economic operators who, in light of the objective assigned to the tax system of the Member State concerned, are in a comparable factual and legal situation (...) If the Commission, in the course of the first two stages of its assessment, has demonstrated the existence of derogations from the common or 'normal' tax regime resulting in a differentiation between undertakings, it is clear from settled case law that such a differentiation is none the less not selective when it arises from the nature or general scheme of the system of charges of which it forms part. In that situation, the Commission must determine, in a third stage, whether the State measure in question is not selective in nature even though it gives an advantage to the undertakings which are able to benefit from it (...). In that regard, given that the differentiations provided for vis-à-vis the common or 'normal' tax regime constitute derogations and are prima facie selective, it is for the Member State to show that those differentiations are justified by the nature and general scheme of its tax system in that they derive directly from the basic or guiding principles of that system. In that context, a distinction must be made between, on the one hand, the ob-

28 P Paepe, "Taxing Games Of Chance: EU State Aid Law And The Member States' Power To Tax Games Of Chance", available at <http://www.mondaq.com/x/257914/Income+Tax/ Taxing+Games+Of+Chance+EU+State+Aid+Law+And+The+Mem ber> accessed 10 January 2017

29 European Commission, Notice of 19 July 2016 on the notion of State aid as referred to in Article 107(1) of the Treaty on the Functioning of the European Union, 2016/C 262/01, paragraphs 126-128.

30 Although different terms have been used over the last 30 years to describe this test, see C Micheau, 'Tax selectivity in European Law of State Aid: legal assessment and alternative approaches' (2015) 3 European Law Review, 323, 328.

31 R Cisotta, 'Criterion of selectivity' in H Hoffmann and C Micheau (eds), State aid law of the European Union (Oxford University Press 2016), 131-132.

32 European Commission, Notice of 19 July 2016 on the notion of State aid as referred to in Article 107(1) of the Treaty on the Functioning of the European Union, 2016/C 262/01

33 European Commission, Notice of 19 July 2016 on the notion of State aid as referred to in Article 107(1) of the Treaty on the Functioning of the European Union, 2016/C 262/01, paragraphs 132-141.

34 European Commission, Notice of 19 July 2016 on the notion of State aid as referred to in Article 107(1) of the Treaty on the Functioning of the European Union, 2016/C 262/0, paragraphs $143-144$ 
jectives attributed to a particular tax regime and which are extrinsic to it and, on the other, the mechanisms inherent in the tax system itself which are necessary for the achievement of such objectives".

The above explained test can be schematised in three steps. In the first step, a tax reference framework must be determined previously, because "the determination of the reference framework has a particular importance in the case of tax measures, since the very existence of an advantage may be established only when compared with 'normal' taxation". ${ }^{35}$

While determining the "common" or "normal" tax regime in a particular Member State, one should bear in mind that this analysis does not require comparing the tax regime applicable in other EU Member States, because the tax differences between Member States are not relevant for determining the normal tax regime for State aid law purposes. ${ }^{36}$ By contrast, the proper benchmark can only be determined by looking at the nature and structure of a tax system as a whole and not by the initial tax base alone, which is especially important in cases where all but few are exempted from a tax (hence only few are subject to

35 Case C-88/03 Portugal v Commission [2006] ECR I-07115 [56]; Case C-408/04P Salzgitter [2013] ERC I-02767, [81]; Case T-210/02 RENV British Aggregates [2012] published in the electronic Reports of Cases (Court Reports - general), [49].

36 P Paepe, 'Taxing Games Of Chance: EU State Aid Law And The Member States' Power To Tax Games Of Chance', available at:<http://www.mondaq.com/x/257914/Income+Tax/ Taxing+Games+Of+Chance+EU+State+Aid+Law+And+The+Mem ber> (last accessed on 10 January 2017).

37 R Luja, 'Revisiting the balance between aid, selectivity and selective aid in respect of taxes and special levies' (2010) 1 European State Aid Law Quarterly, 161, 164.

38 Case T-210/02 RENV British Aggregates [2012] published in the electronic Reports of Cases (Court Reports - general), [49].

39 P Paepe, 'Taxing Games Of Chance: EU State Aid Law And The Member States' Power To Tax Games Of Chance', available at:<http://www.mondaq.com/x/257914/Income+Tax/ Taxing+Games+Of+Chance+EU+State+Aid+Law+And+The+Mem ber> (last accessed on 10 January 2017).

40 For example Case C-279/08 P European Commission v Kingdom of the Netherlands [2011] ECR I-07671 [62].

41 For instance Joined cases C-78/08 to C-80/08 Paint Graphos [2011] ECR I-07611 [49].

42 P Paepe, 'Taxing Games Of Chance: EU State Aid Law And The Member States' Power To Tax Games Of Chance', available at:<http://www.mondaq.com/x/257914/Income+Tax/ Taxing+Games+Of+Chance+EU+State+Aid+Law+And+The+Mem ber> (last accessed on 10 January 2017).

43 B Kurcz and D Vallindas, 'Can general measures be ... selective? Some thoughts on the interpretation of a State aid definition' (2008) 45 Common Market Law Review, 159, 172.

44 A Bartosch, 'Is there a need for a rule of reason in European State aid law? Or how to arrive at a coherent concept of material selectivity?' (2010) 47 Common Market Law Review, 729, 742. tax) or - contrarily - where all but few are entitled to a tax benefit. ${ }^{37}$

In the second step - once the tax reference framework is determined - the "derogatory character" of the tax measure is to be assessed, that is "it must be assessed and determined whether any advantage granted by the tax measure at issue may be selective by demonstrating that the measure derogates from that common regime inasmuch as it differentiates between economic operators who, in the light of the objective assigned to the tax system of the Member State concerned, are in a comparable factual and legal situation". 38

Paepe considers that the demonstration of the derogatory character of the tax measure under scrutiny involves in itself three sub-steps. ${ }^{39}$ Firstly, the objective of the tax measure in question must be determined in order to provide an analytical framework to establish the group of comparable economic operators; and the broader the objective identified the larger the group of economic operators that will be found to be in a comparable situation.

The author remarks that case law reveals that sometimes the objective of the tax measure in question is determined, ${ }^{40}$ whereas in other cases the objective of the tax reference framework is the element to be determined, ${ }^{41}$ concluding that the tax measure at issue and the tax reference framework usually do not coincide. In these situations, the author considers it is unclear which objective should be taken into account. ${ }^{42}$

In this regard, Kurcz and Vallindas also point out that the test established by the Courts refers once to the "measure in question" and at another time to "scheme in question", but they believe that these two words (measure and scheme) are used interchangeably. ${ }^{43}$ In contrast, Bartosch considers that the differentiation between "measure" and "scheme" may indeed have a substantive meaning because if it is the "measure" that is required and sufficient, then Member States would in principle be free to pursue their respective political goals by individual acts even applying to only one single undertaking. However if a "statutory scheme" were required, this would prima facie render it difficult for such measures to be permissible, as the relevant benchmark (directly or indirectly) apply only to a limited number of undertakings, maybe even one. ${ }^{44}$

Moreover, this author has reached the conclusion that most cases in which the EU Courts has explicitly identified the objective pursued by the tax mea- 
sure it seems to identify only one objective. ${ }^{45}$ But in other cases a particular tax measure can pursue other objectives than the objective to generate financial means for the State (for example, environmental or social objectives). The author underlines that in the cases where a non-revenue generating objective was identified, the EU Courts reasoned that the non-revenue generating objective took precedence over the revenue generating objective. In this context, Paepe points out that there is a question that does not find an answer in case law, because it is currently unclear how a tax measure should be assessed when it is pursuing both a revenue generating and a non-revenue generating objective, with both objectives carrying the same weight. ${ }^{46}$

Notwithstanding the need of determining the objective of the tax measure in question, the ECJ reminds that, since the concept of State aid is defined in relation to its effects and not to its objectives, the objective identified cannot impede the qualification of the tax measure as State aid. ${ }^{47}$

The first time that the ECJ referred to "objectives pursued" in the field of selectivity of a tax measure and this objective was regarded to be decisive for the determination of whether a State measure could be regarded to be prima facie selective, ${ }^{48}$ was in its landmark judgment in Adria-Wien Pipeline, when it said that "under a particular statutory regime, a State measure is such as to favour certain undertakings or the production of certain goods within the meaning of article 92(1) of the Treaty (article 107(1) TFEU) in comparison with other undertakings which are in a legal and factual situation which is comparable in the light of the objective pursued by the measure in question". ${ }^{49}$

Bartosch considers that in Adria-Wien the Court of Justice clearly accepted the primordial role to be played by the objectives defined by the Member State itself when devising a regime that differentiated between two (or more) different groups of undertakings. ${ }^{50}$ This author considers that the general acceptance of an objectives-based approach so introduced into the State aid case law by the Adria-Wien ruling does not give Member States a carte blanche to declare all kinds of political goals to qualify as such objectives, which then will have to be endorsed by the Commission, with the competence of the latter being consequently reduced to a mere checking for manifest errors. However, the objectives-based approach solution also reveals a much higher degree of freedom granted to the Member States which in turns casts doubts on the more rigid approach advocated by the Commission in decisions and communications adopted prior to Adria-Wien. ${ }^{51}$

Consequently, it would be highly desirable to maintain a differentiation between "good" or permissible objectives that Member States may pursue without having to justify them in terms of State aid control and impermissible or "bad" objectives that render a given measure materially selective. Notwithstanding this proposal, the author is aware of the practical difficulties it may entail, since not every measure is based on a clear-cut "good" or "bad" objective, because many may feature a mixture of both. Moreover, in many cases, it may be uncertain which objective is a side or subsidiary objective. ${ }^{52}$

Secondly, the group of economic operators or goods in a comparable factual and legal situation should be apprised in light of the objective pursued by the tax measure at stake. While doing this, the EU Courts may find comparable situations ${ }^{53}$ or may not find any comparability at all ${ }^{54}$ or even may use a competition or substitutability test as a proxy. ${ }^{55}$

45 As concluded the EC) in Joined cases C-106/09P and C-107/09P Gibraltar [2011] ECR I-11113, [101] (introduction of a general system of taxation for all companies); Joined cases C-78/08 to C-80/08 Paint Graphos [2011] ECR I-07611 (taxation of company profits) and Case T-210/02 RENV British Aggregates [2012] published in the electronic Reports of Cases (Court Reports general) (environmental protection)

46 P Paepe, 'Taxing Games Of Chance: EU State Aid Law And The Member States' Power To Tax Games Of Chance', available at <http://www.mondaq.com/x/257914/Income+Tax/ Taxing+Games+Of+Chance+EU+State+Aid+Law+And+The+Mem ber> (last accessed on 10 January 2017).

47 Case C-487/06P British Aggregates [2008] ECR I-10515, [85].

48 Bartosch considers that the most outstanding fact in the AdiraWien pronouncement is that the Court was willing to accept a clearly objectives-based approach in the area of material selectivity, see A Bartosch, 'The concept of selectivity' in E Szyszczak (ed.), Research Handbook on European State aid law (Edward Elgar Publishing Limited 2011), 180.

49 Case C-143/99 Adria-Wien Pipeline [2001] ECR I-08365, [41].

50 A Bartosch, 'The concept of selectivity' in E Szyszczak (ed.), Research Handbook on European State aid law (Edward Elgar Publishing Limited 2011), 181.

51 A Bartosch, 'Is there a need for a rule of reason in European State aid law? Or how to arrive at a coherent concept of material selectivity?' (2010) 47 Common Market Law Review, 729, 745.

52 A Bartosch, 'The concept of selectivity' in E Szyszczak (ed.), Research Handbook on European State aid law, (Edward Elgar Publishing Limited 2011), 189-190.

53 Like in Case T-210/02 RENV British Aggregates [2012] published in the electronic Reports of Cases (Court Reports - general) [73].

54 Joined cases C-78/08 to C-80/08 Paint Graphos [2011] ECR I-07611, [55-61].

55 Like the General Court did in Case T-210/02 RENV British Aggregates [2012], [72]. 
Thirdly it must be examined whether the tax measure at issue differentiates between economic operators or goods that are in a comparable factual and legal situation. If this question is answered in the positive, the tax measure will give rise to a selective advantage (unless, the selective nature of the tax measure can be justified in step 3). For example the General Court considers that the fact that certain operators or products are exempted from the tax at issue will lead to a tax differentiation and, therefore, to tax selectivity. ${ }^{56}$ On the contrary, if the question receives a negative answer, the tax measure will therefore not amount to State aid, because there is no tax differentiation and, consequently, no selective advantage. $^{57}$

Luja considers that an analysis of comparability between operators - based on legal and factual circumstances - may have to be done at more than one level. Thus the comparability test may be seen as a species of the nature-and-structure test (or the natureand-general-scheme test), an affirmative answer to which would result in non-selectivity as a result of an exclusion or exemption from tax being a logical part of the special tax or levy at hand given its rationale. $^{58}$

In the third step - lastly, and only in the case that the tax measure in particular has been found selective - it is necessary to verify if that measure is justified by the nature of general logic of the system of which it is a part. ${ }^{59}$ This justification first appeared in case 173/73, Italy v. Commission ${ }^{60}$ in 1974 in an obiter dictum and it was revived in the 1990 not on-

56 Case T-210/02 RENV British Aggregates [2012], [75].

57 P Paepe, 'Taxing Games Of Chance: EU State Aid Law And The Member States' Power To Tax Games Of Chance', available at <http://www.mondaq.com/x/257914/Income+Tax/ Taxing+Games+Of+Chance+EU+State+Aid+Law+And+The+Mem ber> (last accessed on 10 January 2017).

58 R Luja, 'Revisiting the balance between aid, selectivity and selective aid in respect of taxes and special levies' (2010) 1 European State Aid Law Quarterly, 161, 164.

59 It is sometimes used in different terms, such as "justification by the nature or overall structure of the system" or "justification by the inherent logic of the system"; see R Szudoczky and JL Van de Streek, 'Revisiting the Dutch interest box under the EU State aid rules and de Code of Conduct: when a disparity is selective an harmful' (2010) 38(5) Intertax, 260, 267.

60 Case C-173/73 Italy v Commission [1974] ECR I-00709.

61 C Micheau, 'Tax selectivity in State aid review: a datable case

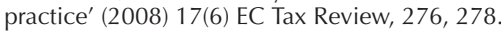

62 Szudoczky and Van de Streek point out that the justification by the nature and general scheme of the tax system has a long history in the case law and the Commission's practice. The ly in the ECJ's case law ${ }^{61}$ but also in the Commission' decisional practice ${ }^{62}$ and lays down the rule that to different situations different treatment should be applied.

The principle of justification by the nature and the scheme of the system is of particular relevance in the field of indirect taxation, which targets production and where a certain harmonisation has been achieved; and it applies in two situations, when it is necessary for the proper functioning of the system or when they reflect the objectives pursued by the State measure. ${ }^{63}$

The ECJ has applied the inner logic excuse in the field of indirect taxes without prejudices in several cases like, for instance, GIL insurance, ${ }^{64}$ but the Court has been traditionally reluctant ${ }^{65}$ to accept this justification in State aid cases on direct taxes until the Gibraltar case, where no derogation from the general tax system was present and the Court accepted this justification in direct taxes as well.

According to Rossi-Maccanico's point of view, this third step implies that the assessment of selectivity merges into the examination of justification, because when an exception to the general tax system is justified by the nature of the scheme, the tax advantage entailed by the exception is not selective, but is rather the general rule for a specific situation. ${ }^{66}$ In this line, Luja goes a step beyond and considers that the comparison and the nature justification can occur not only at the stage of examination of an advantage or the selectivity, but at the verification of the scope of a specific charge or levy. ${ }^{67}$

Commission notice on the application of the State aid rules to measures relating to direct business taxation of 1998 expressively recognised that the selective nature of a measure may be justified by the nature of the general scheme of the system, see R Szudoczky and JL Van de Streek, 'Revisiting the Dutch interest box under the EU State aid rules and de Code of Conduct: when a disparity is selective an harmful' (2010) 38(5) Intertax, 260, 267.

63 J Kociubiński, 'Selectivity criterion in state aid control' (2012) 2(1) Wroclaw Review of Law, Administration \& Economics, 1, 14.

64 Case C-308/01 GIL Insurance [2004] ECR I-04777

65 In 2009, the ECJ Judge Lenaerts pointed out that the ECJ has never accepted the "inner logic" excuse in State aid cases on direct taxes, see K Lenaerts, 'State aid and Direct Taxation, EU Competition Law' in H Kanninen, N Korjus and A Rosas (eds), Contest: Essays in Honour of Virpi Tiili, (Oxford 2009), 291-306.

66 P Rossi-Maccanico, 'The specificity criterion in fiscal aid review: proposals for State aid control of direct business tax measures' (2007) 16(2) EC Tax Review, 90, 96.

67 R Luja, 'Revisiting the balance between aid, selectivity and selective aid in respect of taxes and special levies' (2010) 1 European State Aid Law Quarterly, 161, 163. 
Micheau considers that the application of the strict derogation test in the assessment of the selectivity (which implies that a very broad range of tax measures qualifies as selective in the first step) should be counterbalanced by the function of the nature justification. ${ }^{68}$

Although there are only few cases where the EU Courts concluded that the selective nature of a tax measure was justified, ${ }^{69}$ the $\mathrm{ECJ}^{70}$ has cited as potential justification grounds the purpose of redistribution and the criterion of ability to pay. ${ }^{71}$

Bartosch notes that the case law of the ECJ has conducted the very same assessment as developed in relation to fiscal measures to a number of other areas, showing that the specific assessment of material selectivity has been conceived for purposes of evaluating fiscal measures and spread to a number of other areas. $^{72}$

\section{Recent Shift in the EU Court's Jurisprudence}

Unfortunately the "derogation test" and the traditional three-step analysis did not lead to totally satisfactory results and may be complex to apply when there is no general tax system against which the tax measures can be assessed. In this context the ECJ may find problems at determining the appropriate reference framework in situations in which the entire tax system should be assessed with regard to the selectivity or with regard to stand-alone schemes. ${ }^{73}$ The Commission makes clear that in certain exceptional cases it is not sufficient to examine whether a given

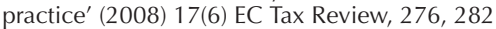

69 Case C-353/95P Tiercé Landbroke [1997] ECR I-07007.

70 Case C-88/03 Portugal v Commission [2006] ECR I-07115, [82].

71 P Paepe, 'Taxing Games Of Chance: EU State Aid Law And The Member States' Power To Tax Games Of Chance', available at <http://www.mondaq.com/x/257914/Income+Tax/

Taxing+Games+Of+Chance+EU+State+Aid+Law+And+The+Mem ber> (last accessed on 10 January 2017).

R Luja, 'Revisiting the balance between aid, selectivity and selective aid in respect of taxes and special levies' (2010) 1 European State Aid Law Quarterly, 161, 164

72 A Bartosch, 'Is there a need for a rule of reason in European State aid law? Or how to arrive at a coherent concept of material selectivity?' (2010) 47 Common Market Law Review, 729, 743.

73 C Micheau, 'Tax selectivity in European Law of State Aid: legal assessment and alternative approaches' (2015) 3 European Law Review, 323, 339. measure derogates from the rules of the reference system as defined by the Member State concerned. It is also necessary to evaluate whether the boundaries of the system of reference have been designed in a consistent manner or, conversely, in a clearly arbitrary or biased way, so as to favour certain undertakings which are in a comparable situation with regard to the underlying logic of the system in question. $^{74}$

The reason for these problems lies on the fact that Article 107(1) of the Treaty does not distinguish between measures of State intervention in terms of their causes or aims, but defines them in relation to their effects, regardless of the techniques used..$^{75}$ Due to this the ECJ had to face two kind of problematic situations.

On the one hand, sometimes the reference system, as defined by the Member State concerned, although founded on criteria that were of a general nature, discriminated in practice between companies which were in a comparable situation with regard to the objective of the tax reform, resulting in a selective advantage. A clear example of this was the joined Cases C-106/09 P and C-107/og P ${ }^{76}$ concerning the Gibral$\operatorname{tar}^{77} \operatorname{tax}$ reform. The Gibraltar Government repealed its entire corporate tax system in order to introduce an entirely new one applicable to undertakings established in its territory. As Micheau stresses, the issue was to assess whether the new tax system was selective in favour of offshore companies, since the latter had no physical presence in Gibraltar, they would have been subject to a very limited tax burden. ${ }^{78}$ The ECJ considered that the tax scheme was selective since the combination of the tax measures

74 European Commission, Notice of 19 July 2016 on the notion of State aid as referred to in Article 107(1) of the Treaty on the Functioning of the European Union, 2016/C 262/01, paragraph 129.

75 Case C-487/06 P British Aggregates [2008] ERC I-10515, [85,89] and the case law cited; Case C-279/08 P European Commission v Kingdom of the Netherlands [2011] ECR I-07671 [51]; and Joined cases C-106/09P and C-107/09P Gibraltar [2011] ECR I-11113, [87].

76 Joined cases C-106/09P and C-107/09P Gibraltar [2011] ECR I-11113.

77 As said before, the Court has never accepted the justification of the nature and the scheme of the system in State aid cases on direct taxes until the Gibraltar case, where no derogation from the general tax system was present and the Court accepted this justification in direct taxes for the first time.

78 C Micheau, 'Tax selectivity in European Law of State Aid: legal assessment and alternative approaches' (2015) 3 European Law Review, 323, 338. 
of the Gibraltar reform, although they seemed to be general in nature, excluded from taxation offshore companies which did not occupy business property and had no employees.

On the other hand there are other situations concerning special-purpose levies, in which the Court found elements indicating that the boundaries of the levy have been designed in a clearly arbitrary or biased way, so as to favour certain products or certain activities which are in a comparable situation with regard to the underlying logic of the levies in question. For instance, in Ferring, ${ }^{79}$ the Court of Justice considered that a levy imposed on the direct sale of medicinal products by pharmaceutical laboratories but not on the sale by wholesalers was selective. In light of the particular factual circumstances - such as the clear objective of the measure and its effects the Court did not simply examine whether the measure in question would lead to a derogation from the reference system constituted by the levy. It also compared the situations of the pharmaceutical laboratories (subject to the levy) and of the wholesalers (excluded), concluding that the non-imposition of the tax on the direct sales by the wholesalers equated to granting them a prima facie selective tax exemption. $^{80}$

79 Case C-53/00 Ferring [2001] ECR I-09067, [19-20].

80 European Commission, Notice of 19 July 2016 on the notion of State aid as referred to in Article 107(1) of the Treaty on the Functioning of the European Union, 2016/C 262/01, paragraph 131.

81 Case C-169/08 Presidente del Consiglio dei Ministri v Regione Sardegna [2009] ECR I-10821.

82 Joined cases C-78/08 to C-80/08 Paint Graphos [2011] ECR I-07611.

83 Joined cases C-106/09P and C-107/09P Gibraltar [2011] ECR I-11113.

84 Case C-279/08 P European Commission v Kingdom of the Netherlands [2011] ECR I-07671.

85 M Lang, 'State Aid and Taxation: Recent Trends in the case law of the ECJ' (2012) 2 European State Aid Law Quarterly, 411, 420.

86 JJ Piernas López, The concept of State aid under EU law: from internal market to competition and beyond (Oxford University Press 2015), 150.

87 JJ Piernas López, The concept of State aid under EU law: from internal market to competition and beyond (Oxford University Press 2015), 150.

88 Joined cases C-106/09P and C-107/09P Gibraltar [2011] ECR I-11113, [71].

89 Joined cases C-78/08 to C-80/08 Paint Graphos [2011] ECR I-07611.

90 P Watte, 'Some Fringe Areas of EU State Aid Lawin Direct Tax Matters' in D Weber and G Maisto (eds), EU income tax law: issues for the years ahead (IBFD 2013), 145-146.
The Court is aware of these inefficiencies arising from the three-step analysis and acknowledges that exceptional cases require another approach. For this reason the ECJ has reacted and keeps refining the test of material tax selectivity. Consequently, in recent cases like Presidente del Consiglio dei Ministri vs Regione Sardegna, ${ }^{81}$ Paint Graphos and Commission ${ }^{82}$ and Spain vs. Government of Gibraltar and United Kingdom $^{83}$ and NOx, ${ }^{84}$ the ECJ has ruled that the question of the presence of an economic advantage and the question of selectivity are not only closely connected, but merge with each other and may eventually be arbitrarily exchanged. ${ }^{85}$

In these judgments the Court has applied the Azores formula concerning justification of a prima facie selective measure by the intrinsic principles of the general fiscal system to these cases in which the Court has perceived a will to circumvent the State aid rules by creating ad hoc general systems and not exceptions to them or, in the Court's words, by using a "certain regulatory technique". ${ }^{86}$

The new orientation in the EU Court's jurisprudence on material tax selectivity is aimed to avoid the circumvention and its main tool is the "end of formalism approach" ${ }^{87}$ since the Court held that any tax differentiation did not necessarily imply the existence of State aid, because it is also required that the measure is capable of pre-determining a particular category of beneficiaries according to their special features. $^{88}$

This new trend in the ECJ case law adds a new dimension to the classic selectivity test in the area of taxation. This new tendency to overcome the formalism has also influenced the case law of the Court concerning other criteria of the concept of aid.

Through these judgments, the ECJ revisited the concept of selectivity and redefined the width of the State aid examination of whole tax regimes, broadening the material selectivity test and thus, the scope of Article 107 TFEU witnessing a shift towards a new "comparability test" or "equality test" meaning that not every case of differentiation is forbidden.

Amidst the above mentioned cases, the landmark case Paint Graphos ${ }^{89}$ before the ECJ is particularly worth mentioning. The Court held that for a finding of selectiveness of a tax regime, it is necessary to identify the "normal" tax regime and to establish that a derogation from that normal regime is afoot, favouring certain taxpayers. ${ }^{90}$ 
In point of fact, in paragraph $49^{91}$ of this case, the ECJ has developed a very wide understanding of the concept of selectivity when it comes to taxation, by establishing a three-step test for selectivity. In the first step, the "normal taxation" under the national reference system, against which any derogation is determined. The second step examines whether the measure in question constitutes a derogation from the reference system so that undertakings which are in a legally or factually comparable situation in light of the objective pursued by the tax system are treated differently. Finally, in a third step, the ECJ examines whether it is possible to justify such derogation by the nature of internal structure of the reference system laid out in the first step. ${ }^{92}$

As Ismer states, this three step test can be understood as imposing a requirement of consistency on Member States, because while the choice of tax base lies with the Member States, they have to transpose this choice in a logically consistent manner. ${ }^{93}$ Consequently, this "new" comparability test implies that tax exemptions can be justified if the measure complies with a requirement of external consistency (objective scope) and an internal consistency requirement that demands the measure to be inherent with the general logic of the tax system.

When it comes to the assessment of a State measure under the heading of material selectivity the new "comparability test" is to be counterbalanced by an objectives-based approach or, in other words, this new test consists of the comparison of two legal and factual situations in order to compare the two differ-

91 Joined cases C-78/08 to C-80/08 Paint Graphos [2011] ECR I-07611, [49]: "In order to classify a domestic tax measure as 'selective', it is necessary to begin by identifying and examining the common or 'normal' regime applicable in the Member State concerned. It is in relation to this common or 'normal' tax regime that it is necessary, secondly, to assess and determine whether any advantage granted by the tax measure at issue may be selective by demonstrating that the measure derogates from that common regime inasmuch as it differentiates between economic operators who, in light of the objective assigned to the tax system of the Member State concerned, are in a comparable factual and legal situation".

$92 \mathrm{R}$ Ismer, 'Judicial review of tax laws: the coherence requirement' in K Messerschmidt and D Oliver-Lalana (eds), Rational Lawmaking under review (Springer 2016), 229.

$93 \mathrm{R}$ Ismer, 'Judicial review of tax laws: the coherence requirement' in K Messerschmidt and D Oliver-Lalana (eds), Rational Lawmaking under review (Springer 2016), 229.

94 R Cisotta, 'Criterion of selectivity' in H Hoffmann and C Micheau (eds), State aid law of the European Union (Oxford University Press 2016), 147

95 A Bartosch, 'Is there a need for a rule of reason in European State aid law? Or how to arrive at a coherent concept of materi- ent tax treatments in light of the objective of the measure.

Under this case law the ECJ is obliged to look into the entirety of the schemes presented to them and analyse them according to the objectives they pursue. On this subject, it is important to remark that the sole formulation of the objectives of a tax measure or system by national authorities implies important consequences as regards the application of the selectivity test. ${ }^{94}$ However the mere absence of any explicit mention of an impermissible objective in the statement of reasons or the legislative history will as such not be sufficient to declare that measure non selective. ${ }^{95}$

\section{Material Selectivity in the State Aid Test and Fundamental Freedoms Analysis: Convergence of Assessment Criteria}

The prohibition on State aid, like the prohibition on fundamental freedoms are aimed to protect free competition in the internal market, but they work in a different way, because State aids rules ensure that Member States do not provide selective advantages to certain undertakings while removing obstacles to the free movement of services, goods, capital and persons is the objective of fundamental freedoms. ${ }^{96} \mathrm{Sim}-$ ilarities between the State aid and the freedom of movement restriction tests have been pointed out by legal scholars, ${ }^{97}$ although the object remains clearly separated.

al selectivity?' (2010) 47 Common Market Law Review, 729, 751.

96 Moreover, it is important to remark that the scope of prohibition on State aid is much broader than that of fundamental freedoms, because it applies to cross-border situations and also to all undertakings, while fundamental freedoms apply only to cross-border situations and prohibit only discrimination of non-residents.

97 F Vanistendael, EU freedoms and Taxation, EATLP Congress, Paris 3-5 June 2004 (Amsterdam: IBFD 2006). R Luja, 'Revisiting the balance between aid, selectivity and selective aid in respect of taxes and special levies' (2010) Issue 1 European State Aid Law Quarterly, 161, 164; W Sauter and H Vedder, 'State aid and selectivity in the context of missions trading: an examination of the ECJ's 2011 NOx Case (C-279/08)' (2010) TILEC Discussion Paper, 11; C Micheau, 'Relationships between fundamental freedoms and State aid law' (2012) 52(5) European Taxation, 209, 210; F Engelen and A Gunn, 'State aid: towards a theoretical assessment framework' in A Rust and C Micheau (eds), State aid and Tax Law, (Kluwer Law International 2013), 135-151; M Villar Ezcurra, 'State aids and energy taxes: towards a coherent reference framework' (2013) 41(6-7) Intertax, 340, 343; R Cisotta, 'Criterion of selectivity' in H Hoffmann and C Micheau (eds), State aid law of the European Union (Oxford University Press 2016), 147-149. 
One thing that seems to be common to State aids and fundamental freedoms is the consideration of the objective pursued by the national measure. In the field of State aid rules, the objective of the measure is taken into consideration regarding the compatibility of the aid with the internal market, whereas regarding fundamental freedom rules, the objective pursued is the basis of the restriction to free movement and has to provide grounds for justification of the restriction in question. Thus, while evaluating measures adopted by a Member State, the Court of Justice has to acknowledge the existence of a valid justification for a restriction to freedoms of movements provoked by such measures and the admissibility of certain objectives under State aid law. ${ }^{98}$

Cissota considers that the comparison regarding the evaluation of the coherence of national legislation is useful in this regard and has found some similarities between these two systems (freedom of movements and State aid), since the ECJ - while taking into consideration the appropriateness of the national legislation for the attainment of the declared objective and assesses the coherence of the legislation - carries out this part of the test substantially in the same way like in Hartlauer ${ }^{99}$ (freedom of establishment) and Adria-Wien Pipeline ${ }^{100}$ (tax on energy considered State aid) cases.

However, this convergence of criteria does not mean a complete analogy. Indeed, Luja alerts that one should keep in mind that the State aid analysis and the analysis of infringement of a fundamental freedom, while going hand in hand, may have totally different outcomes. For instance, if non-taxation would be the benchmark for a State aid analysis (leading up to a vast majority of those subject to tax to being exempt) it may still be that the actual levying of tax on some

98 R Cisotta, 'Criterion of selectivity' in H Hoffmann and C Micheau (eds), State aid law of the European Union (Oxford University Press 2016), 147-149.

99 Case C-169/07 Handelsgesellschaft mbH v Wiener Landesregierung and Oberosterreichische Landesregierung [2009] ECR I-01721, [56-63].

100 Case C-143/99 Adria-Wien Pipeline [2001] ECR I-08365, [52].

101 R Luja, 'Revisiting the balance between aid, selectivity and selective aid in respect of taxes and special levies' (2010) 1 European State Aid Law Quarterly, 161, 164.

102 R Cisotta, 'Criterion of selectivity' in H Hoffmann and C Micheau (eds), State aid law of the European Union (Oxford University Press 2016), 147-148.

103 R Cisotta, 'Criterion of selectivity' in H Hoffmann and C Micheau (eds), State aid law of the European Union (Oxford University Press 2016), 147-148. (who are so discouraged from entering the market) leads to an infringement of fundamental freedoms. ${ }^{101}$

Cissota also alerts about the differences existing during the performance of the test in the field of State aid and in the freedom of movements. Firstly, in the context of freedom of movements, the ECJ has affirmed that national legislation is appropriate for ensuring attainment of the objective pursued only if it genuinely reflects a concern to attain it in a consistent and systematic manner. In this strain of case law, the contrast between the State action and the general objective pursued by its legislation - which reveals an inadmissible incoherence under the freedom of movement rules - has sometimes seemed to be detected as quite stark, while in the domain of State aid an extrinsic objective - which is pursued by the national legislation at issue has to be already considered when the comparison between the situations of the subjects concerned is drawn; as seen, such subjects have to be in a comparable factual and legal situations in light of that objective. ${ }^{102}$

Moreover, when dealing with fundamental freedoms, the Court of Justice does not openly address the question as to the comparability of the situations of the undertakings involved in light of the objective pursued - even if, of course, it verifies whether there is a discrimination or a difference in treatment while it has been shown that under State aid law this is an important branch of the test applied. On the other hand, in the freedoms of movement domain, the analysis is first of all focused on the inclusion of the objective pursued amongst those recognised by the Treaties or by the case law as legitimate objectives while under State aid law every objective, other than the aim of restricting competition or intraEU trade, is, in principle, admissible. ${ }^{103}$

Another point that both systems share in common is the relationship between the notion of selectivity and the proportionality principle (also called equality principle). Micheau remarks that the ECJ has evolved important and restrictive sets of rules to frame the law applicable to a breach of fundamental freedom. In essence, unless they are justified, national measures cannot constitute an obstacle to the application of fundamental freedoms. Depending on the fundamental freedom involved, there are various reasons which can be put forward to justify a restrictive national measure (for example, public morality, public security, jurisprudential justifications, such as the effectiveness of fiscal supervision of the fairness 
of commercial transactions). These restrictions are permissible only if they comply with the principle of proportionality inasmuch as they do not go further than what is necessary to achieve their objectives. ${ }^{104}$

Similarly, the proportionality test has been introduced by the Court with regard to the selectivity criterion in the sphere of State aid. This proportionality test, however, does not apply to assess the departure from the general tax system; it is used to appraise the justification by the logic of the tax system. ${ }^{105}$

Regarding this question, Villar Ezcurra remarks that the assessment of the proportionality criteria in the field of State aid is very similar to that ruled by the ECJ doctrine in Sardinia ${ }^{106}$ regarding fundamental freedoms. Closely related, Sauter and Vedder consider that the principle of equality also plays an important role in the domain of State aid, inasmuch as the assessment of selectivity essentially involves the equality principle since one undertaking may not be favoured compared to another undertaking in a comparable situation. ${ }^{107}$

Following this line of reasoning, Vanistendael highlights the fact that selectivity means discriminatory treatment, the question could come up whether a measure which discriminates between undertakings could at the same time be regarded as State aid and as a restriction on the fundamental freedoms. ${ }^{108}$ This idea is not foreign to EU case law which claims that a tax measure could be regarded as a breach of a fundamental freedom as well as State aid.

Concerning this eventual double qualification, the EC) stated its approach for the first time in the founding Iannelli \& Volpi case ${ }^{109}$ accepting that the same tax measure can fall both within the scope of the rules on State aid and free movement of goods. The Court has maintained its approach over the years, and has applied it recently in the Sardegna case $\mathrm{e}^{110}$ where the Court came to the conclusion that the tax measure at issue constituted a breach of freedom to provide services and also fell within the scope of Article 107 of the TFEU.

In order to assess whether a measure should be regarded not only as State aid but also an infringement of fundamental freedoms, the Court introduced in its pronouncement of Iannelli \& Volpi the "severability test", according to which a State aid whose mere consequence is the preferential treatment of certain domestic products cannot be regarded as violation of free movements of goods:

"those aspects of aid which contravene specific provisions of the Treaty other than Articles 107 and 108 (ex. Articles 92 and 93) may be so indissolubly linked to the object of the aid that it is impossible to evaluate them separately so that their effect on the compatibility or incompatibility of aid viewed as a whole must therefore of necessity be determined in the light of the procedure described in Article 108 (ex. Article 93)".11

This intricate approach of the Court has not been clarified by later case law, thus determining the aspects of the preferential treatment of the State aid which are so indissolubly linked to their object that it is impossible to evaluate them separately is still a complex task that leaves room for debate. ${ }^{112}$

Moreover, as Micheau notes, it is regrettable that the Court has not yet been faced with the concrete application of a double qualification of the same tax measure, in particular with regard to the issue of remedies because the same remedies do not apply to both a breach of fundamental freedoms and a violation of State aid rules. If a tax measure is considered to be an illegal State aid within the meaning of Article 107 TFEU, then the aid should be recovered, however a breach of fundamental freedom would allow the undertaking which has paid the tax at issue to be reimbursed. ${ }^{113}$

104 C Micheau, 'Fundamental freedoms and State aid rules under EU law: the example of taxation' (2012) 52(5) European Taxation, $210,213$.

105 In order to illustrate this, the author refers to the Joined cases C-78/08 to C-80/08 Paint Graphos [2011] ECR I-07611; see also C Micheau, 'Tax selectivity in European Law of State Aid: legal assessment and alternative approaches' (2015) 3 European Law Review, 323, 343.

106 M Villar Ezcurra, 'State aids and energy taxes: towards a coherent reference framework' (2013) 41(6-7) Intertax, 340, 343.

107 However comparability is determined in light of the objective pursued by the measure in question. This means that the equality test that would make a measure non-selective is not an absolute one. On the contrary, this equality is to be determined in light of the objectives of the measure, see W Sauter and H Vedder, 'State aid and selectivity in the context of missions trading: an examination of the ECJ's 2011 NOx Case (C-279/08)' (2010) TILEC Discussion Paper, 11.

$108 \mathrm{~F}$ Vanistendael, EU freedoms and Taxation, EATLP Congress, Paris 3-5 June 2004 (Amsterdam: IBFD 2006).

109 Case C-74/76 lannelli \& Volpi SpA v Ditta Paolo Meroni [1977] ECR I-00557.

110 Case-C-169/08 Presidente del Consiglio dei Ministri v Regione Sardegna [2009] ECR I-10821.

111 Case C-74/76 lannelli \& Volpi SpA v Ditta Paolo Meroni [1977] ECR I-00557, [14].

112 C Micheau, 'Fundamental freedoms and State aid rules under EU law: the example of taxation' (2012) 52(5) European Taxation, $210,214$.

113 C Micheau, 'Fundamental freedoms and State aid rules under EU law: the example of taxation' (2012) 52(5) European Taxation, $210,213$. 


\section{Closing Remarks}

It is clear that the three-step analysis should be improved in order to avoid a circumvention of the material selectivity test through fiscal techniques, as in the Gibraltar case. In this task, a new trend based on a non-formalistic approach which takes into account the underlying objectives of the tax measure is a pragmatic solution and could be useful but, due to the multi-purpose nature of tax measures which very often pursue different goals, ${ }^{114}$ this solution fails to confer the desirable level of legal certainty.

In this context, there is an underlying tension regarding the objectives pursued by Member States. On the one hand, if Member States are allowed to use all sorts of political objectives to justify the tax measures and avoid the qualification of being materially selective, State aid control will be deprived of its effectiveness. As Bartosch asserts, the general acceptance of an objectives-based approach does not give Member States a carte blanche to declare all kinds of political goals to qualify as such objectives,

114 Merola considers that "the controversy surrounding fiscal aid is due to the typical multi-purpose nature of tax measures, which often combine macroeconomic and microeconomic goals (and effects)", M Merola, 'The rebus of selectivity in fiscal aid: a nonconformist view on and beyond case-law' (2016) 39(4) Journal World Competition, 1, 26.

115 A Bartosch, 'Is there a need for a rule of reason in European State aid law? Or how to arrive at a coherent concept of material selectivity?' (2010) 47 Common Market Law Review, 729, 745.

116 Opinion of AG Geelhoed of 18 September 2003 in Case C-308/01 GIL Insurance [2006] ECR I-07115, [76].

117 Since the three-step test has proven to be quite problematic in certain cases, we can find in legal literature some attempts to formulate alternative approaches. For example, Micheau proposes an analysis based on the absence of the measure, called the "but for" test (see C Micheau, 'Tax selectivity in European Law of State Aid: legal assessment and alternative approaches' (2015) 3 European Law Review, 323, 340-341) or Luja recommends the introduction of an additional step that would apply before the threestep analysis in order to determine whether the scope of the tax measure is broad enough (see R Luja, 'Revisiting the balance between aid, selectivity and selective aid in respect of taxes and special levies' (2010) Issue 1 European State Aid Law Quarterly, 161, 161-168 and 'The selectivity test: the concept of sectoral aid' in A Rust and C Micheau (eds), State aid and Tax Law, (Kluwer Law International 2013), 107-118).

118 R Cisotta, 'Criterion of selectivity' in H Hoffmann and C Micheau (eds), State aid law of the European Union (Oxford University Press 2016), 150.

$119 \mathrm{M}$ Merola, 'The rebus of selectivity in fiscal aid: a nonconformist view on and beyond case-law' (2016) 39(4) Journal World Competition, 1, 26.

120 Case T-210/02 British Aggregates v Commission [2006] ERC II-02789 which was set aside by the judgment of the Case C-487/06 P British Aggregates [2008] ERC 1-10515, [92].

121 Joined cases C-106/09P and C-107/09P Gibraltar [2011] ECR I-11113. which then will have to be endorsed by the Commission, with the competence of the latter being consequently reduced to a mere checking for manifest errors. $^{115}$

On the other hand, if the test of selectivity does not take at all into consideration the objective pursued, the selectivity criterion will be enlarged to an unacceptable level and consequently, it would be very difficult for any tax measure to escape from being regarded as selective and, since Advocate General Geelhoed expressed in the Gil Insurance case, ${ }^{116}$ Member States would be deprived of competences they enjoy pursuant to the Treaty provisions.

It is true that the objectives-based approach added recently by the ECJ to the three-step analysis provides Member States a higher degree of freedom and goes beyond the rigid approach advocated by the Commission but it is no less true that the recent refinement of the three-step analysis seems to be rather vague, because the objective pursued by the Member State is decisive for the determination of whether a tax measure could be regarded as materially selective and, thus, it is essential to distinguish permissible goals from impermissible goals, where a clear-cut line cannot be drawn.

Only a case-by-case analysis could shed some light on the concept of material selectivity of tax measures, but in return a case law approach offers a fragmented scenario that impairs legal certainty and that can be taken advantage of in order to circumvent the competition policy constraints. For these reasons and in order to achieve the desirable degree of legal certainty and the desired predictability of Commission's decisions, the author considers that a single unequivocal test should apply. ${ }^{117}$

Moreover, it is clear that the General Court and the Court of Justice have often shown different attitudes regarding the weight in providing ground for a sort of exemption from State aid control and the interpretative value as concerns the objectives set at the national level. ${ }^{118}$ In fact, we have witnessed that every time the General Court attempts to propose alternative approaches, it is almost invariably overruled by the Court of Justice, ${ }^{119}$ as can be clearly seen, for instance, in the British Aggregates ${ }^{120}$ or the Gibraltar ${ }^{121}$ cases.

In light of the above considerations it is legitimate to conclude that case law shows that the practical application of the selectivity criterion is rather ambiguous. When it comes to geographical selectivity, a high 
degree of legal certainty in combination with a more liberal approach on autonomous regions and their competences is working very much to the delight of Member States. But the same cannot be said in the area of material selectivity, because here the jurisprudence of the EU Courts is highly casuistic, at times conflicting and, in essence apparently advocating a wide concept of material selectivity. ${ }^{122}$

122 A Bartosch, 'The concept of selectivity' in E Szyszczak (ed.), Research Handbook on European State aid law (Edward Elgar Publishing Limited 2011), 189-190. 